\title{
Low reduction of HCV-RNA level at week 4 in HIV-1 infected patients with acute HCV Infection
}

\author{
A Vincent, S Jonckheere*, B Kabamba, JC Yombi, D Wilmes, L Belkhir, B Vandercam \\ From 17th International Symposium on HIV and Emerging Infectious Diseases (ISHEID) \\ Marseille, France. 23-25 May 2012
}

\section{Introduction}

The epidemic of acute Hepatitis C-virus infection (AHC) is an on-going issue, especially among MSM patients. Spontaneous HCV clearance rates have been estimated to be between $5-40 \%$, with lower rates among HIV-1 coinfected patients. High rates of sustained virological response have been observed (60-80\%) when patients are treated within 24 weeks of AHC diagnosis. Moreover, a spontaneous $2 \log$ reduction in HCV-RNA might be a good predictor of spontaneous HCV-RNA clearance in HIV-1 co-infected patients. The aim of this study is to analyse the incidence of 2-log-HCV-RNA spontaneous reduction in AHC in HIV-1 infected patients.

\section{Materials and method}

We reviewed medical files of 930 HIV-1-infected patients from our Reference Centre. All patients diagnosed with AHC in 2010-2011 were included. Diagnosis of AHC was based on seroconversion and ALT elevation. HCV-RNA PCR data was collected at time of and on week 4 after diagnosis.

\section{Results}

Eleven patients were included, but only 10 met our diagnostic criteria. One patient was excluded because of missing data. Demographic and clinical data are summarised in Table 1. All patients were MSM. All but 2 patients had genotype 1a HC-virus. On week 4, 3 patients presented with a spontaneous $2 \log \mathrm{HCV}$-RNA reduction. All were diagnosed with genotype 1a AHC.

\section{Conclusion}

Although completed on a small number of patients, this audit suggests that only a low proportion (33\%) of HIV-
Table 1 Demographic data (data shown in numbers (\%) or median)

\begin{tabular}{ll}
\hline Population & \\
\hline Male sex & $9(100 \%)$ \\
Age (median) & 23 \\
BMI (median) & $9(100 \%)$ \\
Transmission risk-factor; MSM & $9(100 \%)$ \\
Ethnicity (Caucasian/Black) & \\
\hline HIV results & 565 \\
\hline CD4-cells count (median) & $<37$ \\
HIV-RNA (copies/mL) (median) & $9(100 \%)$ \\
HAART+ & \\
\hline HCV & $7(78 \%)$ \\
\hline Genotype 1a & $2(22 \%)$ \\
Genotype 4 & 1049740 \\
HCV-RNA To (copies/mL) & 552042 \\
HCV-RNA T+4weeks (copies/mL) & $3(33 \%)$ \\
- 2 log at T+ 4w & $3(100 \%)$ genotype 1a / 0 \\
- 2 log at T+ 4w according to & genotype 4 \\
genotype & \\
\hline Clinical features & 357 \\
\hline AST (IU/L) T0 (median) & 654 \\
ALT (IU/L) T0 (median) & 131 \\
ALT (IU/L) T+4w (median) & \\
\hline
\end{tabular}

1 infected patients presenting with AHC will meet a favourable $2 \log$-HCV-RNA-drop criteria. This is slightly lower than rates reported by NEAT (i.e. 48\%). It implies that these co-infected patients should benefit from a close follow-up in order to start treatment within 24 weeks of AHC diagnosis, whenever it is needed and available.

Published: 25 May 2012

\footnotetext{
* Correspondence: Sylvie.Jonckheere@uclouvain.be

Internal Medicine - Infectious Dieases at Cliniques Universitaires Saint Luc, Bruxelles, Bruxelles, Belgium
}

(C) 2012 Vincent et al; licensee BioMed Central Ltd. This is an Open Access article distributed under the terms of the Creative Commons Attribution License (http://creativecommons.org/licenses/by/2.0), which permits unrestricted use, distribution, and reproduction in any medium, provided the original work is properly cited. 
doi:10.1186/1742-4690-9-S1-P54

Cite this article as: Vincent et al: Low reduction of HCV-RNA level at week 4 in HIV-1 infected patients with acute HCV Infection. Retrovirology 2012 9(Suppl 1):P54.

Submit your next manuscript to BioMed Central and take full advantage of:

- Convenient online submission

- Thorough peer review

- No space constraints or color figure charges

- Immediate publication on acceptance

- Inclusion in PubMed, CAS, Scopus and Google Scholar

- Research which is freely available for redistribution

Submit your manuscript at www.biomedcentral.com/submit

C BioMed Central 